\title{
The Frost in Faulkner: Walls and Borders of Modern Metaphor
}

\author{
Anca PEIU \\ University of Bucharest (Romania) \\ Department of English \\ anca.peiu@lls.unibuc.ro
}

\begin{abstract}
My paper discusses the dialogue between Robert Frost's verse and William Faulkner's works: from the first poems he published as a young writer, especially in his debut volume The Marble Faun (1924), to The Hamlet (1940), an acknowledged novel of maturity. Three world-famous poems: "Birches," "Mending Wall," "Nothing Gold Can Stay" will represent here Frost's metaphorical counterpart. The allegorical borders thus crossed are those between Frost's lyrical New England setting and the Old South of Faulkner's Yoknapatawpha diegesis; between (conventional patterns of) Romanticism and Modernism - in both writers' cases; between poetry and prose; between "live metaphor" and "emplotment" (applying Paul Ricoeur's theory of "semantic innovation"); between (other conventional patterns of) regionalism and (actual) universality. Frost's uniqueness among the American modern poets owes much of its vital energy to his mock-bucolic lyrical settings, with their dark dramatic suggestiveness. In my paper I hope to prove that Frost's lesson was a decisive inspiration for Faulkner, himself an atypical modern writer. If Faulkner's fiction is pervaded by poetry, this is so because he saw himself as a "poet among novelists." Faulkner actually started his career under the spell of Frost's verse - at least to the same extent to which he had once emulated the spirit of older and remoter poets, such as Keats or Swinburne.
\end{abstract}

Keywords: walls - borders, Romanticism - Modernism, regionalism universality.

\section{The Poetic Beginnings of Modernism}

Whether in verse or in prose, poetry may seem obsolete today. But plenty of comfort should come from the fact that to some extent the kind of poetry we are here concerned with already seemed obsolete when it got first published. Robert Frost was an atypical modernist in 1913 and then in 1914, when his first two verse volumes - A Boy's Will and respectively North of Boston - were published in London. Ezra Pound saluted Frost with his typical enthusiasm - yet 
also eagerly advised him to give up his verse musicality - if he was to become genuinely modern. ${ }^{1}$

But it is precisely this verse musicality that makes Robert Lee Frost's genuine trade mark. In his wonderful essay "Robert Frost and the Poetry of Survival," literary critic Jay Parini - himself a distinguished American poet of today and also the author of several exquisite biographies of great writers, one of these being that of William Faulkner - highlights exactly this musical quality of Frost's poems:

The idea behind Frost's "sound of sense" theory is fascinating. "The best place to get the abstract sound of sense is from voices behind door that cuts off the words," Frost explains. "It is the abstract vitality of our speech." In other words, the specific denotation of the words, what we usually think of as "content," is less important than the way the language moves something akin to the "mind's ear." (1993, 263; emphasis mine)

Therefore, Frost's "sound of sense" may provide a link between his (notion of) poetry and that of a French symbolist like Stéphane Mallarmé, to whom modern poetry and literary theory on both shores of the Atlantic owe so much. On the other hand, at the time of his literary debut, Faulkner was keenly aware of this: the first thing he ever published was a poem entitled just like that, "L'Après-midi d'un Faune," as an evident echo to Mallarmé's original poem, in an American literary magazine, on August 6, 1919. Therefore, as Parini states in his abovementioned essay:

Frost, then, is not a naïve chronicler of farm life in rural New England. He is a poet fully aware of every influence, from the ancient writers of Greek and Roman eclogues through the Romantics right up to his immediate contemporaries. Furthermore, he was a "Modernist" in his own way, which is why Ezra Pound - the ringmaster of literary Modernism - found him interesting. (1993, 263; emphasis mine)

The same can safely (and wisely) be affirmed about Faulkner: mock-pastoral rural Yoknapatawpha County, for all its capital Jefferson, is hardly the Old South Arcadia it may deceptively seem to be. If such poems as Frost's here remembered "Birches," "Mending Wall," "Nothing Gold Can Stay" - are as representative of his art as to be included in any anthology of American literature, no matter how "short"

1 The details can be found in William H. Pritchard's Introduction to the Signet Classic Centennial Edition of Poems by Robert Frost, 2001, pp. 1-14.

2 Such is the second volume of The Norton Anthology of American Literature, Shorter Seventh Edition, to which we will refer in this essay for illustration in point of Frost's poems, and which is usually present in all our American Literature courses bibliographies. 
- Faulkner's poems are hardly ever recalled today. No matter how controversial his personality as a mortal, Frost remains America's poet laureate, at least for the best part of the twentieth century. No matter how debatable and fluctuating his rank as a fiction writer, Faulkner remains America's most distinguished poet in prose, for the same best part of the same twentieth century. This was also the way in which he liked to recommend himself, as a "poet among novelists," according to a celebrated interview that Faulkner gave to Jean Stein:

Interviewer: And your contemporaries?

Faulkner: All of us failed to match our dream of perfection. So I rate us on the basis of our splendid failure to do the impossible. In my opinion, if I could write all my work again, I am convinced that I would do it better, which is the healthiest condition for an artist. That's why he keeps on working, trying again; he believes each time that this time he will do it, bring it off. Of course he won't, which is why this condition is healthy. Once he did it, once he matched the work to the image, the dream, nothing would remain but to cut his throat, jump off the other side of that pinnacle of perfection into suicide. I'm a failed poet. Maybe every novelist wants to write poetry first, finds he can't, and then tries the short story, which is the most demanding form after poetry. And failing at that, only then does he take up novel writing. (Faulkner 1956, 2; emphasis mine)

Quite often have literary critics and biographers remarked on young Faulkner's affinities with the romantic poets of old England, like Keats or Shelley, and especially the decadent Victorian Swinburne. Yet at the time of his 1924 debut as a poet with a full book of his own verse, by the volume The Marble Faun, Faulkner may have already found much closer sources (and "anxieties") of influence from such a compatriot poet as Frost, in whose destiny (the spirit of New) England had also played a decisive role. Moreover, the temptation to read this first Faulknerian volume as a tribute to older American masters of world literature is enhanced by the intertextual echo of the title itself, evoking Nathaniel Hawthorne's last romance of 1860, entitled The Marble Fawn. ${ }^{3}$

3 Hawthorne's impact upon young Faulkner's mind is evident from other aspects, likewise. Much like Hawthorne, who could never accept his Puritan forefathers' persecuting Quakers and therefore had changed his own name by adding a personal letter $w$ to make a difference from the original Hathorne of his ancestors, Faulkner added his own letter $u$ to his last name, in order to distinguish himself from old Confederate Colonel Falkner's, his great grandfather, who had sired a double family: the official one plus an illegitimate family, based on his love for an African American slave-woman. Yet more significant is Faulkner's intertextual masterpiece, As I Lay Dying (1930), a modern hybrid of all three classic genres: narrative, poetry and drama. This special book is Faulkner's ultimate tribute to Hawthorne's 1850 classic romance, The Scarlet Letter. 
There seem to be no absolute borders between Hawthorne's and then Frost's New England - on the one hand - and Faulkner's Old South - on the other hand. Regionalism as an approach here is bound to take us down the wrong path: regionalism is the game both Frost and Faulkner played masterfully to allure readers deeper into their metaphorical/plot labyrinths. The same deep darkness gives these writers an unmistakable aura of the national spirit they share, beyond even the cultural frontier between Romanticism and Modernism.

Let us just remember Frost's 1916 poem "Birches” here:

When I see birches bend to left and right

Across the lines of straighter darker trees,

I like to think some boy's been swinging them.

[...]

You may see their trunks arching in the woods

Years afterwards, trailing their leaves on the ground

Like girls on hands and knees that throw their hair

Before them over their heads to dry in the sun. $(2008,785)$

And now let us consider Faulkner's "Prologue" to his 1924 verse volume, The Marble Faun:

The poplar trees sway to and fro

That through this gray old garden go

Like slender girls with nodding heads,

Whispering above the beds

Of tall tufted hollyhocks,

Of purple asters and of phlox;

Caught in the daisies' dreaming gold

Recklessly scattered wealth untold

About their slender graceful feet

Like poised dancers, lithe and fleet. $(1960,11)$

Not only in point of lyrical imagery - that is, from Frost's metaphor of birches to that of Faulkner's poplars - do these two poems communicate, but also in their musicality, especially in their rhythm. The same "sound of sense" - as Frost would put it. Girlish grace in Frost's birches-imagery becomes dryad-like loveliness to young Faulkner's faun - alas, here cast in marble! For the poplars in Faulkner's "old garden" are surrounded by zestful homely flowers reminding one of Emily Dickinson's (poetic) gardening skills (see especially her poem 285, “The Robin’s my Criterion for Tune” [Dickinson 2001, 131]). 
The one regret in Faulkner's marble faun as a first person lyrical voice is missing (mortal) freedom. Faulkner's faun is made of marble, to adorn the ancient garden of a terrestrial Eden: ironically standing for carnal desire, the statue is doomed to remain for ever cold to life's temptations:

Why am I sad? I?

Why am I not content? The sky

Warms me and yet I cannot break

My marble bonds. That quick keen snake

Is free to come and go, while I

Am prisoner to dream and sigh

For things I know, yet cannot know,

'Twixt sky above and earth below.

The spreading earth calls to my feet

Of orchards bright with fruits to eat,

Of hills and streams on either hand;

Of sleep at night on moon-blanched sand:

The whole world breathes and calls to me

Who marble-bound must ever be. (Faulkner 1960, 12; emphasis mine)

As in an echo of Dickinson's poem 986 "A Narrow Fellow in the Grass” (2001, 459) - Faulkner's "quick keen snake" is regarded with awestruck esteem (and even envy) for its freedom. Yet the marble faun can paradoxically just "dream and sigh" for the earthly world it intuits with no hope of ever getting to know.

For "Earth's the right place for love" - as the lyrical voice in Frost's poem proclaims in the memorable conclusion of the poem starting from a recollection of birches:

I'd like to get away from earth awhile

And then come back to it and begin over.

May no fate willfully misunderstand me

And half grant what I wish and snatch me away

Not to return. Earth's the right place for love:

I don't know where it's likely to go better.

I'd like to go by climbing a birch tree,

And climb black branches up a snow-white trunk

Toward heaven, till the tree could bear no more,

But dipped its top and set me down again.

That would be good both going and coming back.

One could do worse than be a swinger of birches.

(2008, 785-786; emphasis mine; emphasis in the original: "toward") 
The Frost in Faulkner first awoke the poet in the novelist soon to become. That first thrill of The Marble Faun would still vibrate between the lines of Faulkner's Yoknapatawpha diegesis, even as late in his career as The Hamlet.

\section{Et in Arcadia Ego - A Shared Nostalgia for Classicism}

With both Frost and Faulkner, the fictive American rural setting is (mock)Arcadian and a-temporal - or rather an impossible return to Romanticism, to that romantic vein of mid-nineteenth century Transcendentalism, out and away from the ineluctable urbanization and industrialization of the two writers' native country, growing rapidly ever bigger and ever more estranged from its (fatally) idealized original values. Ironically, with both the poet and the novelist to-be, the same impulse to a romantic (or intellectual) idealization of a (not so much older) rural America in illo tempore should express innermost despair at this process of alienation - i.e. the Faulknerian Snopes-ization - of a fictive homeland soon to be lost for ever.

The Snopeses are mature Faulkner's modern masks of classic Pan: from Ike Snopes, wooing the cow on Jack Houston's land, to Mink Snopes - Houston's remorseless and Flem's vengeful killer; further on to Wallstreet Panic Snopes. The satyr with the magic pipes (and no Mozartian flute) is Flem Snopes himself, the nucleus of a hallucinatory network of kinfolks, of older and younger upstarts, invading Flem's dystopian Arcadia - or what is left of a Yoknapatawpha lost to ruthless rural gangsters, whose basic survival law is (everlasting) nepotism.

According to consecrated American literary criticism, The Hamlet (1940), the first volume of the Snopeses' Trilogy, is also the last one of Faulkner's absolute achievements in his Yoknapatwpha diegesis - if we ignore Intruder in the Dust (1948). From this moment on, all through the three volumes of The Hamlet, The Town (1957) and The Mansion (1959), the Snopeses would assert themselves as the consummate invaders (or trespassers), leaving no Snopes-free village or town. The raw newcomers, the ferocious upstarts would soon claim the best of everything. We simply cannot fail to see the prophetic message of the Snopeses' saga - here and now, in our globalized everyday world. Thus Faulkner's Frenchman's Bend appears as all the more important for today's readers: it feels like home, wherever on earth we may read its hallucinatory stories.

\section{The Faulkner in Frost}

If Frost were to become a writer of fiction - for a gifted story-teller in verse he obviously was - he may have turned out into someone quite like Faulkner. And likewise, if Faulkner had pursued his poetic career, he may have developed into 
someone quite like Frost. Even their impact upon a contemporary readership is a fine argument for that: Faulkner had to prove a lot of patience (obstinacy?) until he was eventually accepted by the American publishing houses of his day. Illustrious French professional readers and thinkers - such as Sartre, Malraux had discovered the merits of Faulkner's art long before Americans did. On the other hand, Great Britain was the country of Frost's first two volumes of (mature) poetry - A Boy's Will (1913) and North of Boston (1914) - before American publishing houses found any profit in his books.

Faulkner won the Nobel Prize in Literature in 1950. Frost was nominated to it thirty-one times and never got it. Both Frost and Faulkner have remained what they call "controversial writers," because of their conservative political views while still alive and afterwards, in life as well as in fiction. Their dark side in poetry and fiction has been politely covered by labels with frail borders, in both cases: Frost, the poet "in the American grain," Faulkner, the Old South storyteller. In Frost's verse tales there is plenty of drama - and likewise can drama be enjoyed in Faulkner's fiction, enlivened by secret soliloquy, as if only available to the reader's mind. In both writers' works there is a deep current of humor, from tender (self)irony to implacable sarcasm aiming at human nature as such. Let alone their biographers, who have come with plenty of juicy "memories" to prove that neither Frost, nor Faulkner could have been really "nice persons" to those who knew them better - whether family or friends; or just neighbors for a while. (Authors') misanthropy has a high price when it informs such pages of high literature that are so hard to ignore.

Therefore, what remains to be said here - not as an apology but rather as a kind of approach in good faith - is just another theoretical argument, in favor of our attempt at discerning the Frost in Faulkner, offered by Paul Ricoeur's notion of "semantic innovation" in his book Time and Narrative. The French thinker's masterpiece came out in the 1980s, two decades after both Frost and Faulkner had died. Although there is no mention of the Americans in either The Rule of Metaphor (1984a) or Time and Narrative (1984b) - the French philosopher's abstract demonstration that semantic innovation is the source of both poetry and literary narrative could only too well refer to Frost and then to Faulkner:

The Rule of Metaphor and Time and Narrative form a pair: published one after the other, these works were conceived together. Although metaphor has traditionally belonged to the theory of "tropes" (or figures of discourse) and narrative to the theory of literary "genres," the meaning-effects produced by each of them belong to the same basic phenomenon of semantic innovation. In both cases this innovation is produced entirely on the level of discourse, that is, the level of acts of language equal to or greater than the sentence. With metaphor, the innovation lies in the producing of a new semantic 
pertinence by means of an impertinent attribution: "Nature is a temple where living pillars ..." The metaphor is alive as long as we can perceive, through the new semantic - and so to speak in its denseness - the resistance of the words in their ordinary use and therefore their incompatibility at the level of a literal interpretation of the sentence. The displacement in meaning the words undergo in the metaphorical utterance, a displacement to which ancient rhetoric reduced metaphor, is not the whole of metaphor. It is just one means serving the process that takes place on the level of the entire sentence, whose function it is to save the new pertinence of the "odd" predication threatened by the literal incongruity of the attribution. With narrative, the semantic innovation lies in the inventing of another work of synthesis - a plot. By means of a plot, goals, causes, and chance are brought together within the temporal unity of a whole and complete action. It is the synthesis of the heterogeneous that brings narrative close to metaphor. In both cases, the new thing - the as yet unsaid, the unwritten - springs up in language. Here a living metaphor, that is, a new pertinence in the predication, there a feigned plot, that is, a new congruence in the organization of events. In both cases the semantic innovation can be carried back to the productive imagination and, more precisely, to the schematism that is its signifying matrix. In new metaphors the birth of a new semantic pertinence marvelously demonstrates what an imagination can be that produces things according to rules: "being good at making metaphors," said Aristotle, "is equivalent to being perceptive of resemblances." But what is it to be perceptive of resemblance if not to inaugurate the similarity by bringing together terms that at first seem "distant" then suddenly "close"? It is this change of distance in logical space that is the work of the productive imagination. (Ricoeur 1984b, ix - x; emphasis mine)

If Faulkner's novel The Hamlet (1940) represents the best choice for our hypothesis here, then Frost's poem "Mending Wall" (1914) should be its best correspondent - since both poem and novel have for a nucleus an ambiguous (and characteristically cynical) proverb from Benjamin Franklin's collection in Poor Richard's Almanack. Frost's version of the old proverb - itself a mean(ingful) adagio to an adage stemming from an essential biblical commandment ("Love your neighbor, yet don't pull down your hedge" - proverb 339 [Franklin 1914, 36]) says just: "Good fences make good neighbors." It becomes a key to an unforgettable modern poem, and then to a memorable modern novel - both American and dealing with the old (pre-American) theme of border crossings. Since the proverb represents a mock-Franklinesque heirloom, it will function within the confinements (or delusive frontiers) of the American Dream - apparently shared by freedom-dreamers, actually serving map-makers with a decisive power. 
In Frost's poem there is a classic sense of symmetry: the line "Something there is that doesn't love a wall" delimitates and establishes two specific sections in the poem, which also benefits by what Ricoeur may call "emplotment." Therefore there is a narrative dimension to it, and also a dramatic one - as in most of Frost's best-known poems. The first person lyrical voice recounts a spring story, the "mending wall" moment of two countryside neighbors. The poem is thus cleverly made to illustrate by its leitmotifs - the above-quoted line plus the dry conventional proverb - two sections in its structure.

The voice telling the story is at once melancholy, skeptical, lucid:

Before I built a wall I'd ask to know

What I was walling in or walling out,

And to whom I was like to give offense. (Frost 2008, 778; emphasis mine)

Yet just before that the poem's inner monologue had evoked the neighbor's proverb-cliché and then the narrator's perplexing issue of a hypothetical cow in this (far from) bucolic picture:

He only says, "Good fences make good neighbors."

Spring is the mischief in me, and I wonder

If I could put a notion in his head:

Why do they make good neighbors? Isn't it

Where there are cows? But here there are no cows.

(Frost 2008, 777-778; emphasis in the original text)

Still in Faulkner's Frenchman's Bend there is a cow - and a crucial cow it is, too. ${ }^{4}$ Tragicomic, grotesque, outrageous - the issue of the cow highlights the Snopeses' turpitude. It is the cow of Mink Snopes, grazing on Jack Houston's pasture. No more than a yearling, a heifer - at first, the cow grows up into (more than) a healthy animal. Not in the least bothered by the illegal trespassing, Mink claims the cow to feed his family on its meat. But Jack Houston sues his shameless neighbor and wins the trial. Rather than paying fairly what he owes his neighbor, Mink Snopes shoots Jack Houston dead with just one shell, as less than necessary to kill a small animal. Mink's infamy is of Dostoevskian extraction in its dense shades of black.

But before that, the same cow becomes the object of Ike Snopes's amorous attention. Ike is the Snopes clan's idiot. Consequently, another member of the

$4 \quad$ Faulkner would soon produce his own parody of this notorious cow-issue of his novel The Hamlet: the short-story "Afternoon of a Cow" - which can be studied now either as part of the volume Uncollected Stories of William Faulkner (1979) or as part of the volume The Best of Bad Faulkner (1991b). Again, the hint at his literary debut as a poet under the spell of Mallarmé's notorious poem "L'après-midi d'un faune" is tale-telling. 
same clan, Launcelot Snopes (Lump - for family and friends) not only removes a plank from the cow's barn, but also sets a price for lookers-on (or rather lookersin?). Voyeurism functions here as another way of crossing borders.

Ike's romance with the cow - once claimed by both Mink Snopes and Jack Houston - may have been prompted itself as a parody of that old Faulknerian poem, mentioned at the beginning of this essay, with the classic faun revisited by Mallarmé, Faulkner's symbolist precursor in his obsession with the turbulent ancient god Pan. Or it may be read as a salute to Bottom with his donkey head, seducing Titania the Queen of Fairies in Shakespeare's play "A Midsummer Night's Dream." Then why could it not have been prompted (also) by Frost's celebrated poem "Mending Wall"? Intertextuality brings together all these masters of "semantic innovation" - according to Ricoeur's still pertinent theory. But then intertextuality itself has been an inexhaustible instance of border crossings between the best minds of our world's writers.

Anyway, the feud around (and then the trial upon) the cow in Faulkner's Frenchman's Bend starts from a tense dialogue between Jack Houston - who would pay his commonsensical victory by his own life - and Mink Snopes Houston's murderer, who would return from Parchman, the terrible prison for the life-convicts of legendary Yoknapatawpha, thirty-eight years later, to also kill his cousin Flem, who had not lifted a finger to save Mink, his kinsman. But Mink's vengeful comeback would only occur in The Mansion (1959) - the final volume of the Snopeses' Trilogy.

The ominous dialogue previously referred to occurs on the very last pages of "Book One: Flem," in the novel The Hamlet:

"I reckon you know where that yearling is," Houston said.

"I can guess," Snopes said.

"All right," Houston said. He was not shaking, trembling, anymore than a stick of dynamite does. He didn't even raise his voice. "I warned you. You know the law in this country. A man must keep his stock up after ground's planted, or take the consequences."

"I would have expected you to have fences that would keep a yearling up," Snopes said. Then they cursed each other, hard and brief and without emphasis, like blows or pistol-shots, both speaking at the same time and neither moving, the one still standing in the middle of the steps, the other still squatting the gallery post. "Try a shot-gun," Snopes said. "That might keep it up." (Faulkner 1991a, 100; emphasis mine)

Mink Snopes may have been a villain, but he certainly knew some proverbs by Franklin - the founding father figure of (believers in) the American Dream all around the world. Moreover, the upstart clan of the scruple-less Snopeses also 
included I.O. Snopes, a schoolteacher and also a notorious collector of proverbs. The border between genuine wisdom (or 'live metaphor'?) and cliché (or popular quip?) is too frail to resist the Snopeses' blunt crossings.

\section{"Nothing Gold Can Stay" in Yoknapatawpha}

Before he dies, shot with just one shell like (less than) an animal, Jack Houston remembers the best of his life. This was his romance with Lucy Pate, his wife, absurdly (and symbolically) killed by his own stallion. The selective omniscient narrator's voice reads in a deliberately self-contained key, safely away from cheap sentimentalism, thus giving in its stream-of-consciousness the full measure of Houston's grief.

After years of wandering, Jack Houston had returned to Frenchman's Bend only for the sake of his school-days' sweetheart. His yearning for her lay deeper than consciousness and defied any conventional way of expression. Jack Houston's final visions in Chapter Two of "Book Three: The Long Summer" is devoid of perfunctory "romance" - evoking the fierce fidelity of the girl who had helped him with his precarious studies and then waited for him:

The woman Houston married was not beautiful. She had neither wit nor money. An orphan, a plain girl, almost homely and not even very young (she was twenty-four) she came to him out of the home of a remote kinswoman who had raised her, with the domestic skill of her country heritage and blood and training and a small trunk of neat, plain, dove-colored clothes and the hand-stitched sheets and towels and table-linen which she had made herself and an infinite capacity for constancy and devotion, and no more. And they were married and six months later she died and he grieved for her for four years in black, savage, indomitable fidelity, and that was all. (Faulkner 1991a, 227)

Lucy Pate - Jack Houston's worshipped wife - may anticipate feminine portraits in Gabriel García Márquez's One Hundred Years of Solitude - such as the beautiful Remedios, perhaps: both girls were orphans, yet their absences were just as powerful as their tentative instances of presence. Lucy Pate's picture here in Jack Houston's final stream-of-consciousness recollection of their unromantic love-story is remarkable by its melancholy conciseness and sobriety of style.

Elegy is compressed between the above-quoted prose lines as it is in the following poetry lines from Frost: 
Nature's first green is gold,

Her hardest hue to hold.

Her early leaf's a flower;

But only so an hour.

Then leaf subsides to leaf.

So Eden sank to grief,

So dawn goes down to day.

Nothing gold can stay. (Frost 2008, 787)

Frost's 1923 poem "Nothing Gold Can Stay" quoted above may or may not have been at the back of Faulkner's mind when he wrote such life-stories in a paragraph. But the classic intensity of the elegiac tone in both instances eludes any borders between poetry in verse and poetry in fiction; between New England and the Old South; between (conventional) Romanticism and (provisional) Modernism.

\section{"Words, Words, Words" - or the (Almost Lost) Art of Reading}

Not very much later - actually in 1955, just fifteen years after The Hamlet yet four years before The Mansion, the final volume of the Snopeses' saga - Flannery O'Connor, a merciless brilliant writer of the same Old South as Faulkner's and one of his outstanding and outspoken admirers, would publish a particular short story about the cliché-ridden discourse of a dull southern lady, whose daughter was a genuine and helpless philosopher. The story is called - sarcastically - "Good Country People" and pertains to the volume entitled - even more sarcastically, after another one of its own short-stories - A Good Man Is Hard to Find.

Not even the would-be didactic (and fatefully unconvincing) claim to "local color" can paint pink the mind limitations - whether "natural" or deliberate (i.e. dictated by hypocrisy) - of such literary characters as the above mentioned. The sharp contrast between the safe emptiness of an old popular "witty saying" and the disturbingly revelatory meaning of a defying new metaphor - remember Ricoeur - still remains a matter of debate in literature, whether written or read.

At least one decade before M. M. Bakhtin's theories of voicing and polyphony in fiction - as affirmed especially in Problems of Dostoevsky's Poetics (1929) - and somehow even anticipating Bakhtin's concept of the dyphonic (i.e. selfcontradictory) word in The Dialogic Imagination (1981) - Frost believed in the sensuous power of words, which can be confirmed by a famous fragment from one of the poet's letters to one of his friends: "Words exist in the mouth, not in books. You can't fix them and you don't want to fix them.” Literary critic William H. 
Pritchard used this statement as an insightful argument in his introductory study to the Signet Classics Centennial Edition of Frost's two earliest poetry volumes (Pritchard 2001: 9; emphasis mine). Faulkner wanted desperately to still believe in words, as a poet, hence he challenged their incantatory power even when having such an overwhelming character as Addie Bundren (in As I Lay Dying) say bitterly: "[...] that words are no good; that words don't ever fit even what they're trying to say at" (Faulkner 2000, 171; emphasis mine).

Therefore, to all those who have already started doubting (and even mourning) literature today, here is the disquieting answer of such unforgettable writings whether as poetry or fiction, or drama - that should go to prove a basic aesthetic truth: that intelligent readers will still need their favorite art, although its artists have no better tools than poor words.

\section{Works Cited}

Bakhtin, M. M. 1970 [1929]. Problemele poeticii lui Dostoievski. [Problems of Dostoevsky's Poetics.] Trans. into Romanian by S. Recevschi. Bucureşti: Editura Univers.

2004 [1981]. The Dialogic Imagination. Ed. Michael Holquist, trans. Caryl Emerson and Michael Holquist. Austin: University of Texas Press.

Dickinson, Emily. 2001 [1955]. The Complete Poems of Emily Dickinson. Ed. Thomas H. Johnson. New York, Boston, London: Back Bay Books, Little, Brown \& Co.

Faulkner, William. 1956. "The Art of Fiction.” Paris Review no. 12. Interviewed by Jean Stein. http://www.theparisreview.org/interviews/4954/the-art-offiction-no-12-william-faulkner (Last accessed 29 January, 2013)

1960 [1924; 1933]. The Marble Faun and A Green Bough. Preface by Phil Stone. New York: Random House.

1965 [1959]. The Mansion. New York: Vintage Books, Random House. 1967 [1957]. The Town. London: Chatto \& Windus.

1979. Uncollected Stories of William Faulkner. Ed. Joseph Blotner. New York: Random House.

1991a. [1940]. The Hamlet. New York: Vintage International, A Division of Random House.

1991b. The Best of Bad Faulkner. Ed. and with a Preface by Dean Faulkner Wells. San Diego, New York, London: Harcourt, Brace, Jovanovich.

1996 [1948]. Intruder in the Dust. London: Vintage Classics, Random House. 2000 [1930]. As I Lay Dying. New York: The Modern Library.

Franklin, Benjamin. 1914 [1776]. Poor Richard's Almanack. Waterloo, Iowa: U.S.C. Publishing Co. 
Frost, Robert. 2001 [1913; 1914]. Poems by Robert Frost: A Boy's Will and North of Boston, with an Introduction by William H. Pritchard and an Afterword by Peter Davidson. New York: Signet Classics. Centennial Edition. 2008 [1979]. In The Norton Anthology of American Literature, Shorter Seventh Edition, ed. Nina Baym et al., 775-790. New York, London: W. W. Norton \& Company.

Márquez, Gabriel García. 2000 [1967]. One Hundred Years of Solitude. Trans. from the Spanish by Gregory Rabassa. London: Penguin Books.

O’Connor, Flannery. 1971 [1955]. The Complete Stories. New York: Farrar, Straus and Giroux.

Parini, Jay. 1993. "Robert Frost and the Poetry of Survival." In The Columbia History of American Poetry, eds. Jay Parini and Brett C. Miller, 260-283. New York: Columbia University Press.

Pritchard, William H. 2001 [1989]. Introduction to Poems by Robert Frost: A Boy's Will and North of Boston, 1-14. New York: Signet Classics. Centennial Edition. Ricoeur, Paul. 1984a [1975]. Metafora vie. [The Rule of Metaphor.] Trans. into Romanian and foreword by Irina Mavrodin. Bucureşti: Editura Univers. 1984b [1983]. Time and Narrative. Volume I, trans. Kathleen McLaughlin and David Pellauer. Chicago, London: The University of Chicago Press. 